\title{
Malaysian University Undergraduates' Perceptions towards Comprehensive Online Instructions amidst COVID-19
}

\author{
Nor Azikin Mohd Omar ${ }^{1}$, Zailani Jusoh ${ }^{1}$, Shaidatul Akma Adi Kasuma ${ }^{2, *}$ \\ ${ }^{1}$ Centre for English Language Studies, Universiti Sultan Zainal Abidin, Kuala Nerus, 21300, Malaysia \\ ${ }^{2}$ School of Languages, Literacies and Translation, Universiti Sains Malaysia, 11800, Malaysia
}

Received September 14, 2020; Revised October 25, 2020; Accepted November 25, 2020

\section{Cite This Paper in the following Citation Styles}

(a): [1] Nor Azikin Mohd Omar, Zailani Jusoh, Shaidatul Akma Adi Kasuma , "Malaysian University Undergraduates' Perceptions towards Comprehensive Online Instructions amidst COVID-19," Universal Journal of Educational Research, Vol. 8, No. 12, pp. 7131 - 7140, 2020. DOI: 10.13189/ujer.2020.081280.

(b): Nor Azikin Mohd Omar, Zailani Jusoh, Shaidatul Akma Adi Kasuma (2020). Malaysian University Undergraduates' Perceptions towards Comprehensive Online Instructions amidst COVID-19. Universal Journal of Educational Research, 8(12), 7131 - 7140. DOI: 10.13189/ujer.2020.081280.

Copyright@2020 by authors, all rights reserved. Authors agree that this article remains permanently open access under the terms of the Creative Commons Attribution License 4.0 International License

\begin{abstract}
The global pandemic COVID-19 has halted all face-to-face educational meetings and shut down academic institutions. Educational activities, are therefore, undertaken remotely at the safe comfort of individuals' home. This unprecedented situation calls for a research on university students' perceptions and their readiness for comprehensive online instructions. Thus, this study primarily aims to investigate these issues further. The questionnaire was distributed to the students in higher institutions in Malaysia through the link of Google Form. Findings indicated that students' readiness for online learning is not optimal, and they require a lot of support from universities and lecturers in areas of financial assistance, internet accessibility, timely feedback on assessments and constant academic engagement. However, there is an indication that suggests students studying at research universities (RUs) have more positive perceptions towards online instructions, than those in non-research universities (NRUs) - which might be due to RUs' better establishment of learning facilities, equipment, resources and pedagogical approaches. In ensuring continuity of learning amidst this trying time, the pedagogical approaches to teaching and learning must change. All stakeholders from practitioners, students, parents and families, government and private sectors, education markets, academic institutions and the public at large must be responsible and contribute to realising the best possible
\end{abstract}

online learning environment for the current and future generation of learners.

Keywords Online Instructions, Online Learning, Students' Readiness, Higher Institutions, Malaysia, COVID-19

\section{Introduction}

The United Nation [1] describes COVID-19 as a global health crisis that is killing people, spreading human suffering, and upending human lives. The global pandemic has devastatingly affected many important sectors of a nation - economic, social, trades, businesses and education. While this outbreak affects everyone, it is particularly detrimental to specific social groups in vulnerable positions including youth [1].

In effort to curb the spread of COVID-19, academic institutions in affected nations have cancelled all face-to-face meetings and are closed indefinitely [2]. This results in about 80 percent of the world's learners (over a billion students) unable to go to school or universities [3]. In managing the situation and continuing with teaching and learning, instructions have been conducted online, spread out over various synchronous and asynchronous tools. 
Peking University for instance, has been closed since Spring 2020 and is currently practicing online instructions [4]. Despite everyone's best effort, the disruption to the usual learning practice may affect the quality of education [1], [5].

Prior to this crisis, many tertiary institutions have launched online learning as a critical aspect to their long-term strategic plan, while others are just beginning to make the transitions from face-to-face instructions to online environment [6]. Popular arrangement that combines both face-to-face lessons with online activities, such as flipped classrooms and blended learning are therefore, compulsorily employed by educators in attending to students' needs for physical classroom meetings and individualised online learning, or personalised learning experience (PLE). Blended learning is viewed as the "new traditional models" or the "new normal" due to its high adoption in higher learning institutions that drives technology integration in courses [7], p. 1.

However, while many institutions are still warming up and adapting to the needs of blended environment, the rapid spread of the airborne COVID-19 virus halts all face-to-face classroom instructions and necessitates the delivery to be conducted fully online. This change raises panic among administrators, academics, students and the public alike due to its effect on teaching and learning performance, quality of instructions, university's ability to support online instructions, technical issues, facilities and equipment, and essentially, students' achievement.

As a nation affected by COVID-19, Malaysia imposes the Movement Control Order (MCO) that prohibits its citizen from going out socially since 18 March 2020 [8]. Academic institutions from schools to universities were shut down where physical classes, examinations, meetings, offices, academic and social gatherings, and society and club events are postponed or cancelled.

Based on instructions from their governing bodies, educators have launched online teaching and learning practice from home. While primary and secondary schools do it to ensure pupils do not fall behind in the acquisition of knowledge and skills, tertiary institutions like universities conduct online classes and assessments to sustain their semester by semester progress - as university education largely affects students' future in terms of career, economy, and well-being [9].

\section{Problem Statement}

Based on The Universities and University Colleges Act (UCCA, 1971), the universities in Malaysia are governed by the Ministry of Higher Education. Under the unprecedented circumstance of COVID-19, the public and private universities are given the flexibility to decide on their teaching and learning procedure and duration of a semester. While some universities follow the Ministry's guide to resume their semester in June 2020, other universities were more proactive in tackling the issues and have already commenced with comprehensive online instructions [10].

While synchronous and asynchronous online classes are manageable, comprehensive online instruction also includes new instructional design, coursework assessments, tests, examinations, discussion, consultation, supervision, marking and gradings and so forth. In online environment, students' course achievement indeed depends on regular study, submissions of assignments, frequency of sessions and logins, and proof of reading the course information packets [11]. To some extent, educators and students are aware, if not familiar, of online tools and resources through their practice of flipped classroom and blended learning. In fact, due to the accessibility to internet services, more students opted for online learning rather than traditional face-to-face settings [12]. However, educators and students often face with issues of low completion rates and high dropouts [13], [14], as they are met with new challenges such as lecture delivery, new sets of assessments, learning progress, large number of students, internet connection, technological facility and equipment [15].

All things considered; this study aims to examine university students' perceptions of comprehensive online instructions. Prior to the outbreak, online instruction is a personal choice for many students. In the current unprecedented situation, online instruction is a must, for all whether they like it or not - hence, might pose as an added pressure. The novelty of this study comes from the difference between having the option to do online learning; and having no other choice but to do it. While students have been introduced to a variety of learning management system (LMS), online tools, games and activities throughout their studies, they have yet to experience a comprehensive online instruction or e-learning for an indefinite period [9]. This study, therefore, observes the following research questions (RQ)

i How do Malaysian university students perceive comprehensive online instructions amidst COVID-19 outbreak?

ii Is there any significant difference in students' perceptions on comprehensive online instructions based on

a). gender?

b). learning institutions?

\section{Related Literature}

Research on online instructions has been extensively ongoing since over a decade, and the areas of the more recent research included students' perceptions and readiness [16]-[21]; dimensions and sub-dimensions of online learning [12], [15], [22]-[26]; factors influencing 
readiness [20], [27]-[28]; predictors of students' engagement and achievement in online learning [11], [13], [29]; effectiveness of online learning [30]; students' motivation and satisfaction in online learning [24], [31] [33] ; challenges of online learning [14], [34]; and pedagogy of online classes [4], [32]- [37].

\subsection{Factors that Affect Online Instructions}

Online learning is presently viewed as a conventional mode of learning as higher institutions keep rolling out online courses, resulting in a growing number of MOOCs and online programmes made accessible to the public [28], [38]. Online learning involves synchronous and asynchronous communication within a virtual environment that provides students with the flexibility and opportunities to participate regardless of time and space [12] - hence, equates a flexible personal learning environment (PLE) [13], [39].

Like physical environment, students' success in online instructions depends on their ability to engage in the learning process [12]. On the contrary, online learning emphasises independent learning and promotes autonomy and self-regulated strategies [39]. Self-regulated learning is a critical factor to online learning success [23], [38]. Rohayani, Kurniabudi and Sharipuddin [20] and Gay [27] used the term e-readiness to describe readiness in online learning, and considered it the most critical aspect in higher education.

Ideally, the pedagogy of online learning should include the components of expository, practice, exploratory and collaborative [2], with five high impact principles - high relevance between student learning and online instructional design; effective delivery of online instructional information; learning supports from instructors; high quality participation to deepen and widen learning; and contingency plan to manage unexpected situations [4].

Guided by student-student interactions in online environment, Kurucay and Inan [31] employed Social Constructivism and Community of Inquiry as their theoretical underpinnings. Greenhow and Lewin [40]; p. 8-9; grounded Social Constructivism as drawing "on the idea that learning is situated in the context of circumstances, activity or culture", that "what is known resides not only in the individual, a position advanced by cognitive constructivists, but also in the collaboration and interaction among many”. This follows scholars' assertion that virtual learning gives more opportunities to learn information, additional access to learning resources and various networks for collaboration that creates a global educators-learners ecosystem [12], [16].

However, Toven-Lindsey, Rhoads and Lozano [35] found that in a number of massive open online courses (MOOCs), learning activities relied primarily on one-directional relationship where knowledge is transferred from instructors to students - an objectivist-individual approach, with some efforts made towards a more constructivist-individual and constructivist-group approaches that are the ideals of online learning. De Freitas, Morgan and Gibson [13] similarly echoed the polarising debate of MOOCs potential to revolutionise higher education due to concerns over quality of teaching and learning provision and low course completion rates; as Wladis, Conway and Hachey [14] predicted higher college drop-outs among students who enrolled in online courses.

Therefore, in an online environment, materials that are pedagogically-sound, cultivate students' self-discipline and self-direction as successful learners and accessible to students with disabilities must be produced. In this regard, Van Rooij and Zirkle [28] and Chiasson et al. [6] called for the collaboration between content experts, instructional designers and multimedia specialists at an institution. Educators must introduce new approaches by including variations of video lectures, materials, notes, interactive activities such as quizzes, games and digital media content. Besides, interactions through social media and peer assessment increase the completion rate in the provided tasks [13]. Fundamentally, online assessments must determine students' readiness for new concepts, use system to support students, provide information about teaching and learning state, and identify students at risk of underachieving [2].

Gillet-Swan [34] cautioned that these requirements necessitate higher levels of technological competency and proficiency among educators, and add to the burden of their regular academic workload. Moreover, often, only a small pool of academics are interested to learn and implement online learning [2]. This is because their knowledge in technology tools influences the quality of information presented, their system uses and students' satisfaction during course delivery [27]. Thus, incentives and compensations in terms of time, resources, funding and learning opportunities must be clear and visible as developing online materials is more time intensive than a face-to-face course [6], [28].

Essentially, an online programme must be designed well enough to promote students' acquisition of 21st century skills, employability and real-world preparation through media-rich content development and data-driven environments [16]; p. 469. Often, however, the one-size-fits-all approach in online learning isolates students from their peers and limits their participation in the learning process, and these issues have influenced their contributions in in group activities [34]. This contradicts the very essence of online learning that is intended to connect, foster collaboration, and engage users in the learning process [16]. Therefore, a good instructional design must take into consideration individual differences and student-centred course design to motivate students' participation in online environment [16]. 


\subsection{Gender Differences in the use of Online Instructions}

Computer culture and internet technology have always been associated with men [39], [41]. It has been pointed out that men have more favourable experience and better proficiency in the use of computers and technology compared to women [39]. However, studies indicated that the concept of gender is not statistically significant on students' actual engagement with online instructions [18]; but is a significant measure of the students' self-assessment of skills and competences in online environment [42]- [43]. For instance, Cuadrado-Garcia et al. [43] found that female students showed higher participation in viewing resources, uploading documents and commenting on tasks, and did not report any problems when using online technology. On the contrary, male students stated that they need help when writing long posts on online discussions and when using online software. Bruestle et al. [42] argued that both male and female students showed positive attitudes towards online learning as e- learning has been an integral part of their lives. Although female students were modest in describing their experiences and competences in e-learning, they were skillful, more active and frequented online activities and classes. Both genders, on the other hand, showed no significant differences in their engagement with online instructions [42].

\subsection{Students' Willingness and Readiness in Online Instructions}

Based on Nardozi's [44] argument, willingness refers to the eagerness to do something (i.e. students' understanding of the importance of the activity); while readiness refers to the level of competency (i.e. students' knowledge of the activity and the strategies they adopt). The two terms are often viewed in relation to each other.

Students' readiness for online instructions are often measured based on several dimensions and sub-dimensions. The Online Learning Readiness Scale or E-learning Readiness Scale created by Hung et al. [18] that was adopted by many scholars [24], [33], consisted of five dimensions - computer/internet self-efficacy, online communication self-efficacy, self-directed learning, learner control, and motivation towards e-learning. In 2016, Hung [18] re-emphasised self-directed learning and communication self-efficacy, and added institutional support and learning-transfer self-efficacy as dimensions. In 2015, Yu and Richardson [45] created another measure of readiness - the Student Online Learning Readiness (SOLR) Instrument - with three competencies - social competencies with classmates and instructors, communication competencies and technical competencies.

Based on the 2010 Online Learning Readiness Scale, Hung et al. [18] reported that Taiwanese college students had high computer/internet self-efficacy, motivation for learning and online communication self-efficacy; but possessed low learner control and self-directed learning. Kırmızı [33] and Hung [25] presented self-directed learning as the main predictor of success that is innately critical to online learning. Broadbent and Poon [12] narrowed down several self-regulated strategies that positively correlated with academic achievement to time management, metacognition, effort regulation and critical thinking; while the strategies that were less influential were rehearsal, elaboration and organisation.

Hung [25] reported from an examination of in-service teachers taking online courses whereby - the more teaching years they had, the higher their self-directed tendencies; while the fewer the teaching years, the higher their communication self-efficacy. The teachers with master's degrees had a higher communication self-efficacy and learning-transfer self-efficacy than those with bachelor's degrees. These findings supported Hung et al.'s [18] earlier observation where the higher-grade college students exhibited significantly greater readiness for self-directed learning, online communication self-efficacy, motivation for learning and learner control, compared to their peers of lower grades.

The male teachers showed greater readiness for learning-transfer self-efficacy than the female teachers [25]. Hao [19] shared the same observation that males and higher grade students were more prepared for flipped learning; and that students' readiness could be predicted via course grades, self-directed readiness and group work preference. Relatedly, Kurucay and Inan [31] found that students who communicated and interacted with others performed significantly better in an online course and viewed online collaboration more favourably after the experience, than those who worked individually.

Besides self-directed learning, learner control and motivation were other main predictors of success [33]. While skills and attitudes influenced students' readiness [20], motivation influenced student's satisfaction in online learning [33]. Yilmaz [24] concurred that readiness served as a significant predictor for students' satisfaction and motivation in online learning - in his case, a flipped classroom. The findings may be seen in relation to Bhagat et al.'s [16] conclusion that learners' trust towards an online course is the key for its successful implementation, if they believe the course benefits them. However, instead of looking at willingness or readiness, Bhagat et al. [16] examined students' perceptions of online learning and underlined four factors - instructor characteristic, social presence, instructional design and trust.

\subsection{Instructors and Students' Roles in Online Instructions}

The fundamental tenets of online instructions are its flexibility for individualised learning and possibilities to promote a more student-centred environment. Therefore, students are expected to play the roles of active, 
responsible learners who listen and read, complete problems and answer questions, explore simulation and resources as well as collaborate with peers while online [2]; with less controlled teaching from instructors [6].

However, this does not mean that instructors are less active in online environment. In fact, educators are central to online education and determine the success or failure of a course as they play multiple roles - from the delivery of meaningful content and giving constant instructions, to monitoring students' active engagement - all by maintaining a small online presence [2], [16], [27]. Their efforts do not go to waste as the experience resulted in increased confidence that made them better instructors in face-to-face settings [6]. Most importantly, students valued the instructors' roles as course designers and organisers, as well as facilitators for technology and discussions [17].

\section{Materials and Methods}

The study is quantitative in nature. Data were collected through an online questionnaire that was distributed to students in Malaysian higher education within the duration of one month (late March 2020 - late April 2020).

On 18 March 2020, Malaysia imposed the restriction of movement as a preventive measure in response to the pandemic COVID-19. In time of the unprecedented situations when the pandemic has taken a significant toll across the world, there is uncertainty over whether university students will be able to return to their institutions after the MCO is lifted. In adding to the repertoire of literature, the situation presents the most suitable opportunity to seek students' opinions on the execution of online instructions.

Prior to the distribution, the questionnaire was piloted to 30 students from a tertiary institution. After the pilot data was analysed and the questions improved, the questionnaire was distributed to university students across Malaysia through the researchers' networks of acquaintances to reach its target population, i.e. Malaysian students enrolled at public and private higher institutions through Google form. This is to ensure that all students had equal chance of being involved in this study as the link was shared with representatives from all universities.

The questionnaire was divided into five sections, excluding the consent and demographic information. The areas of concern included:

Section A: Circulation of COVID-19 information provided by universities.

Section B: University's effort in maintaining physical and psychological health of the students.

Section C: University's information on academic activities in time of COVID-19 crisis.

Section D: Students' perceptions of the execution of online instructions during MCO and throughout the crisis.
The focus of this research is mainly on Sections $C$ and $D$, with emphasis on students' readiness for online instructions and expected assessment practices in online environment, as well as the types of support required from their university.

\section{Data Analysis}

SPSS 25.0 was used to analyse the data. Descriptive analysis using percentage, mean and standard deviation and inferential analysis using independent sample $t$ test were performed. Responses were collapsed into 3 categories (Disagree, Neutral, and Agree) from 5 in the original version (Strongly Disagree, Disagree, Neutral, and Agree, Strongly Agree) to simplify data analysis. To find out the overall perception regarding online instructions, composite scores were calculated.

\subsection{Demographic Information}

As of 2018 [46], there were about half a million students enrolled in Malaysian public universities. Out of these, a total of 680 students from public universities and a few other higher learning institutions such as Polytechnics, and University Colleges participated in the study. However, 17 responses had to be removed as they did not meet the requirement for inclusion in the study. According to Krejcie and Morgan [47], the sample size is sufficient for this study, Table 1 presents the demographic information of the respondents. Out of 663 respondents, $70 \%$ were female students while the remaining $30 \%$ were male students. Majority of the respondents were from UniSZA (39\%), followed by USM (20\%), and UITM (13\%). The respondents' institutions are categorised based on their status as research university (RUs) (25\%) and non-research university (NRUs) (75\%).

Table 1. Demographic profile of respondents

\begin{tabular}{|c|c|c|c|}
\hline & & $\mathrm{N}$ & $\%$ \\
\hline \multirow{2}{*}{ Gender } & Male & 196 & 30 \\
\hline & Female & 467 & 70 \\
\hline \multirow{8}{*}{ Institutions } & $\begin{array}{l}\text { University of Sultan Zainal } \\
\text { Abidin (UniSZA) }\end{array}$ & 255 & 39 \\
\hline & $\begin{array}{l}\text { Universiti Sains Malaysia } \\
\text { (USM) }\end{array}$ & 134 & 20 \\
\hline & $\begin{array}{c}\text { MARA Universiti of } \\
\text { Technology Malaysia } \\
\text { (UiTM) }\end{array}$ & 83 & 13 \\
\hline & Sultan Idris Education & & \\
\hline & $\begin{array}{c}\text { University Malaysia } \\
\text { (UPSI) }\end{array}$ & 45 & 8 \\
\hline & $\begin{array}{c}\text { The University Malaysia } \\
\text { Terengganu (UMT) }\end{array}$ & 44 & 8 \\
\hline & Other public universities & 76 & 11 \\
\hline & Other HEIs & 26 & 4 \\
\hline
\end{tabular}




\subsection{Perceptions towards Online Learning}

Perceptions towards online learning are measured based on three components:

1. Students' readiness to learn online (8 items)

2. The types of support expected from the university (6 items)

3. Expectation about assessment practices (4 items)

Based on the categories classified by Oxford [48], we have examined the level of the students' readiness, the support and assessment practices that were expected by the students. The categories are determined based on the mean scores as depicted in Table 2. Analysis was also performed based on items in each category.

Table 2. Classification of level of perception (adapted from [40])

\begin{tabular}{cc}
\hline Level of perception & Mean score range \\
\hline Negative & $1-2.33$ \\
Moderate & $2.34-3.67$ \\
Positive & $3.68-5.00$ \\
\hline
\end{tabular}

Table 3 presents results for both individual and overall components. Based on the table, out of three components, the perceptions of two components fall into moderately positive level. The mean scores for readiness to learn online, and expectation about assessment practices are 3.51 and 3.50 respectively. The only component that falls into positive perception category is the types of support expected from the institutions ( $M=4.53)$. This is expected as online instructions require a tremendous amount of support from both university and lecturers involved. To make learning more effective, there must be a coordination among various parties.

Table 3. Perceptions towards online instructions based on components

\begin{tabular}{cccc}
\hline Component & $\begin{array}{c}\text { No. of } \\
\text { items }\end{array}$ & Mean scores & Level \\
\hline $\begin{array}{c}\text { Students' readiness to } \\
\text { learn online }\end{array}$ & 8 & 3.51 & Moderate \\
$\begin{array}{c}\text { Support expected from } \\
\text { the university } \\
\text { Expectation about } \\
\text { assessment practices } \\
\begin{array}{c}\text { Overall perceptions on } \\
\text { the execution of online } \\
\text { instructions }\end{array}\end{array}$ & 6 & 4.53 & High \\
\hline
\end{tabular}

Table 4 presents results for the component of students' readiness for online learning, by items. This component assesses readiness in terms of knowledge (prior experience, technical), mental readiness (motivation), and physical readiness (gadgets/ tools/ internet read). The findings also indicate that the percentage of agreement for items measuring readiness range from $45 \%$ to $76 \%$. Item with the highest agreement is "I am equipped with tools and gadgets for online learning during MCO" while the lowest agreement is recorded by item "I have no problem with internet connection if online learning is carried out". What the findings indicate is that although the students reported to have the necessary gadgets and tools for online learning, they have issues with internet connection that is very much needed for online learning to take place.

Table 4. Descriptive statistics of students' readiness to learn online (in \%)

\begin{tabular}{|c|c|c|c|c|}
\hline No & Statements & Disagree & Neutral & Agree \\
\hline 1 & $\begin{array}{l}\text { I am mentally ready if the online learning is carried out during the } \\
\text { MCO. }\end{array}$ & 19 & 21 & 60 \\
\hline 2 & I am motivated to learn online if it is carried out during the MCO. & 18 & 27 & 55 \\
\hline 3 & $\begin{array}{c}\text { I am equipped with ICT tools and gadgets for online learning } \\
\text { during MCO. }\end{array}$ & 10 & 14 & 76 \\
\hline 4 & $\begin{array}{l}\text { I am able to use ICT tools and gadgets to learn online and complete } \\
\text { tasks if online learning is carried out during the MCO. }\end{array}$ & 10 & 21 & 69 \\
\hline 5 & $\begin{array}{c}\text { I have no problem with internet connection if online learning is } \\
\text { carried out during the MCO. }\end{array}$ & 30 & 24 & 45 \\
\hline 6 & $\begin{array}{l}\text { I am ready to go for online learning during the MCO because I am } \\
\text { used to online learning. }\end{array}$ & 18 & 27 & 55 \\
\hline 7 & $\begin{array}{l}\text { I can learn effectively for online learning if it is done during the } \\
\text { MCO. }\end{array}$ & 18 & 27 & 55 \\
\hline 8 & I was already exposed with online learning throughout my study. & 16 & 32 & 52 \\
\hline
\end{tabular}


Table 5. Descriptive statistics for support expected from education providers (in \%)

\begin{tabular}{|c|c|c|c|c|}
\hline No & Statements & Disagree & Neutral & Agree \\
\hline 1 & $\begin{array}{l}\text { University needs to provide clear guidelines on the execution of online } \\
\text { learning if the online learning is to be done during the MCO. }\end{array}$ & 3 & 9 & 89 \\
\hline 2 & $\begin{array}{l}\text { University needs to provide appropriate platforms if the online learning } \\
\text { is to be done during the MCO. }\end{array}$ & 1 & 8 & 91 \\
\hline 3 & $\begin{array}{l}\text { University needs to provide help and technical support if I encounter } \\
\text { problem in relation to online learning during the MCO. }\end{array}$ & 1 & 7 & 92 \\
\hline 4 & $\begin{array}{c}\text { Lecturers need to provide clear guidelines on the execution of online } \\
\text { learning during the MCO. }\end{array}$ & 0 & 6 & 94 \\
\hline 5 & $\begin{array}{l}\text { Lecturers need to provide clear guidelines and instructions on the } \\
\text { assessments if online learning is to be done during the MCO. }\end{array}$ & 0 & 6 & 94 \\
\hline 6 & $\begin{array}{l}\text { Lecturers need to be readily available to communicate or provide } \\
\text { support to students if online learning is to be done during the MCO. }\end{array}$ & 0 & 7 & 93 \\
\hline
\end{tabular}

Findings from Component 2, 'the types of support expected from the university and lecturers' are presented in Table 5. This component consists of six items on the roles of university and lecturers during online learning. The types of support required are providing information and learning platforms, as well as technical support. All items in this category recorded a high percentage with agreement ranging from $89 \%$ to $94 \%$ - indicating students' high expectations of support of the institutions and the lecturers. The roles of university and lecturers are, therefore, crucial in easing students' experience with online learning.

Component 3 assessing 'students' expectation towards assessment practices' consisted of 4 items. The results are presented in Table 6 and show that the percentage of agreement to the items in this component varies from $42 \%$ to $61 \%$. With regard to 'getting feedback on online assessment', $55 \%$ agree to the statement. Only $42 \%$ of the respondents agree with the statement that 'the final examination should be done online' while quite a large number (34\%) disagree with this statement. Meanwhile, statements regarding 'assessments such as quizzes and assignments' (items 2 and 3) see a higher level of agreement (61\%). This means that, although students agree to have continuous online assessments, they are somewhat reluctant to take the final examination online.

Table 6. Descriptive statistics of expectation towards assessment practices (in \%)

\begin{tabular}{|c|c|c|c|c|}
\hline No & Statements & Disagree & Neutral & Agree \\
\hline 1 & $\begin{array}{l}\text { Feedback on continuous } \\
\text { assessment should be } \\
\text { given online during the } \\
\text { MCO. }\end{array}$ & 18 & 27 & 55 \\
\hline 2 & $\begin{array}{l}\text { Individual/ group } \\
\text { assignments should be } \\
\text { done online during the } \\
\text { MCO. }\end{array}$ & 16 & 23 & 61 \\
\hline 3 & $\begin{array}{l}\text { Quizzes/ tests/ } \\
\text { assessments should be } \\
\text { done online during the } \\
\text { MCO. }\end{array}$ & 17 & 23 & 61 \\
\hline 4 & $\begin{array}{l}\text { Final examination } \\
\text { should be done online } \\
\text { during the MCO. }\end{array}$ & 34 & 24 & 42 \\
\hline
\end{tabular}

\subsection{Perceptions of Students on Online Learning Based on Gender}

An Independent Sample t-test was performed to investigate if there is a statistically significant difference in the total perception towards online learning based on gender. Prior to performing the test, all assumptions were checked to ensure there were no violations of the assumptions for t-test. The result of the t-test is shown in Table 7. There is no significant difference in the scores for female $(\mathrm{M}=3.87, \mathrm{SD}=.68)$ and male students $(\mathrm{M}=3.77$, $\mathrm{SD}=.72) ; \mathrm{t}(660)=1.58, \mathrm{p}=.115-$ indicating that gender does not affect students' perceptions towards online learning.

Table 7. Perceptions towards online learning based on gender

\begin{tabular}{cccccc}
\hline Gender & $\mathrm{N}$ & Mean & $\mathrm{SD}$ & $\mathrm{t}$ & $\begin{array}{c}\text { P value } \\
\text { (sig) }\end{array}$ \\
\hline Male & 196 & 3.77 & .72 & 1.58 & .115 \\
Female & 467 & 3.87 & .68 & & \\
\hline
\end{tabular}

\subsection{Perception towards Online Learning Based on Institution}

Table 8. Perception towards online learning based on institution

\begin{tabular}{|c|c|c|c|c|c|}
\hline Institution & $\mathrm{N}$ & Mean & SD & $\mathrm{t}$ & $\begin{array}{c}\text { P value } \\
\text { (sig) }\end{array}$ \\
\hline $\begin{array}{c}\text { Research } \\
\text { university (RUs) }\end{array}$ & 167 & 4.09 & .63 & 5.42 & $.00^{* *}$ \\
\hline $\begin{array}{l}\text { Non- research } \\
\text { university (NRUs) }\end{array}$ & 496 & 3.75 & .70 & & \\
\hline
\end{tabular}

The differences in perceptions towards online learning during COVID-19 pandemic among students in different universities were also examined. In addressing the RQ, another set of independent sample t-test was performed. Results indicate that there was a significant difference in the mean scores for RUs $(\mathrm{M}=4.09, \mathrm{SD}=.63)$ and NRUs $(\mathrm{M}=3.75, \mathrm{SD}=.70) ; \mathrm{t}(661)=5.45$, at $\mathrm{p}=.00$ - suggesting that students from institutions of different categories do perceive online learning differently. Students from RUs perceived online learning more positively compared to those in NRUs. 


\section{Discussions}

Based on the results presented above, the respondents generally reported positive perceptions towards online instructions. However, when individual components are examined, perceptions towards readiness, and expected assessment practices are found to be in moderate category. This finding is in line with those from previous studies [11], [15]. In this case, the results could perhaps be attributed to a number of reasons. Students are generally familiar with online learning as they have been exposed to the approach since they begin their tertiary education. Prior to this, online learning was mainly conducted through internal online platform (LMS) subscribed by an institution in blended mode, rather than fully online. Surely, their savviness in technology helps learning, but having face-to-face class makes a lot of difference [7]. Face-to-face learning allows live interaction where course content and learning materials are directly communicated to one person or in a group. Though live online sessions do promote direct communication, the lack of physical presence and poor connectivity lessen students' enthusiasm about online learning [7]. Similarly, assessment is a major issue among the students. Although they did not seem to mind having continuous online assessment, they seem to be concerned with regards to taking summative assessment on the same platform. This is perhaps due to the unfamiliar practice of having final online examinations in Malaysian universities, thus creating uncertainties among students.

The only component that recorded highly positive perception is in relation to the expected roles of the institutions and lecturers. Students' expectation from the university and lecturers was very high. This is because going fully online is a new experience for many, thus, requires tremendous amount of support from institutions and lecturers in the forms of information, facilities and expertise. As suggested by previous researchers [17], [49-51], online learning will be a meaningful experience if sufficient supports are provided. Students are more motivated if instructors guide and facilitate them in using technology and conducting discussions, and be supportive of their needs and feelings, which eventually leads to improvement in online learning.

This study was also interested in investigating differences in perceptions among students of different genders. The fact that there was no significant difference in students of different gender's perception towards online learning is not surprising as previous studies [42] have produced similar results. Bruestle et al. [42] found that both males and females showed similar attitudes towards online learning; despite the findings by Morahan-Martin [39] that men are better at computers and technology. Therefore, it is fair to state that in the case of online learning as investigated in the present study, tech-savviness is not the only determining factor that influences people's perception.
Besides the findings discussed above, a notable result with regards to the perceptions of students in different categories of institutions, must be highlighted. Students who are enrolled in research universities (RUs) were more positive than those from the NRUs. RUs such as USM has been executing online learning since the beginning of MCO period, while NRUs such as UniSZA and UPSI started their online learning in June. Both UniSZA and UPSI alleviated the tension for online learning by waiting for a cooling-off period, where during the time, the universities prepared the lecturers for online teaching pedagogy and solved the internet connection issues faced by the students [10]. In Malaysia, RUs are more established and better equipped in their learning facilities and exposure to the latest pedagogical approaches compared to NRUs that are relatively new to online learning [52]. Due to this, students in RUs developed a more positive outlook towards online learning. These results partially supported the findings by Thang et al. [53], who found that Malaysian students in the RUs were more inclined towards online self-tests/quizzes/practice for learning of English, whereas students from NRUs opted for the more didactic tools such as digital videos and LMS - when asked about their preferred ICT tools for online learning. The fact that the students in NRUs perceived online learning in less positive manner indicated their limited exposure to online practices that affected their confidence, resulting in high dependence on lecturers as the main educational source.

\section{Conclusion}

The COVID-19 outbreak has affected a lot of sectors, including the field of education. This pandemic has called for a drastic transformation to the academic scene where all learning is forced to be conducted remotely. In this unprecedented situation whereby educators are caught off guard, an "online movement" for learning must take place to sustain and maintain quality education. This study found that students' readiness for online instructions is not at its optimum. It is discovered that they need support in terms of timely feedback on the tasks given and consistent synchronous or asynchronous interactions by the lectures, and technical support such as financial assistance, sufficient bandwidth and the right technology for online instructions. In response to the significant changes, it is imperative for the institutions to see online learning as the (temporary) silver bullet for learning that will continue to persist post-pandemic. All stakeholders from practitioners, students, parents and families, government and private sectors, education markets, academic institutions and the public at large are in need of critical knowledge to keep pace with the online transition, explore its potential and realise the need to accept that online instructions are now part of our 'new normal' that was once viewed as impossible. 


\section{REFERENCES}

[1] United Nations, "Everyone Included: Social Impact of COVID-19," Department of Economic and Social Affairs Social Inclusion, 2020. [Online]. Available: https://www.un.org/development/desa/dspd/everyone-inclu ded-covid-19.html. [Accessed: 23-Apr-2020].

[2] C. Hodges, S. Moore, B. Lockee, T. Trust, and A. Bond, "The Difference Between Emergency Remote Teaching and Online Learning," Educause review, 2020. [Online]. Available:

https://er.educause.edu/articles/2020/3/the-difference-betwe en-emergency-remote-teaching-and-online-learning?utm_so urce $=$ Newsletter + de + innovación+educativa $+\% 28 d o c e n t e s$ \%29\&utm_campaign=45e0a08d6b-EMAIL_CAMPAIGN_ 2019_01_15_LDTEC_COPY_01\&utm_medium=email\&ut m_. [Accessed: 01-May-2020].

[3] N. McCarthy, "COVID-19's staggering impact on global education,” World Economic Forum, 2020. [Online]. Available:

https://www.weforum.org/agenda/2020/03/infographic-covi d19-coronavirus-impact-global-education-health-schools/. [Accessed: 23-Apr-2020].

[4] W. Bao, "COVID-19 and online teaching in higher education: A case study of Peking University,” Hum. Behav. Emerg. Technol., no. March, pp. 113-115, 2020.

[5] M. S. Andrade, R. M. Miller, M. B. Kunz, and J. M. Ratliff, "Online learning in schools of business: The impact of quality assurance measures,” J. Educ. Bus., vol. 95, no. 1, pp. 37-44, 2019.

[6] K. Chiasson, K. Terras, and K. Smart, "Faculty Perceptions of Moving A Face-To-Face Course To Online Instruction," $J$. Coll. Teach. Learn., vol. 12, no. 3, pp. 321-240, 2015.

[7] C. Dziuban, R. Graham, Charles, P. D. Moskal, A. Norberg, and N. Sicilia, "Blended learning: The new normal and emerging technologies,” Int. J. Educ. Technol. High. Educ., vol. 15 , no. 3, 2018

[8] K.H.D. Tang, "Movement control as an effective measure against Covid-19 spread in Malaysia: an overview," Z Gesundh Wiss. pp.1-4, 2020.

[9] S. Dhawan."Online learning: a panacea in the time of Covid-19 crisis", Journal of Educational Technology Systems, vol 49, no. 1, pp. 5-22, 2020.

[10] BERNAMA, "UPSI To Implement Online Teaching in Line with Ministry’s Instruction,” Bernama, Kuala Lumpur, 18-Jun-2020.

[11] J. W. You, "Identifying significant indicators using LMS data to predict course achievement in online learning," Internet High. Educ., vol. 29, pp. 23-30, 2016.

[12] J. Broadbent and W. L. Poon, "Self-regulated learning strategies \& academic achievement in online higher education learning environments: A systematic review," Internet High. Educ., vol. 27, pp. 1-13, 2015.

[13] S. I. De Freitas, J. Morgan, and D. Gibson, "Will MOOCs transform learning and teaching in higher education? Engagement and course retention in online learning provision,” Br. J. Educ. Technol., vol. 46, no. 3, pp. 455-471, 2015 .

[14] C. Wladis, K. M. Conway, and A. C. Hachey, "Assessing readiness for online education - Research models for identifying students at risk,” J. Asynchronous Learn. Netw., vol. 20, no. 3, pp. 97-109, 2016.

[15] A. H. Aldholay, Z. Abdullah, T. Ramayah, O. Isaac, and A. M. Mutahar, "Online learning usage and performance among students within public universities in Yemen," Int. J. Serv. Stand., vol. 12, no. 2, pp. 163-179, 2018.

[16] K. K. Bhagat, L. Y. Wu, and C. Y. Chang, "Development and validation of the perception of students towards online learning (POSTOL),” Educ. Technol. Soc., vol. 19, no. 1, pp. 350-359, 2016.

[17] M. L. Hung and C. Chou, "Students' perceptions of instructors' roles in blended and online learning environments: A comparative study," Comput. Educ., vol. 81, pp. 315-325, 2015.

[18] M. L. Hung, C. Chou, C. H. Chen, and Z. Y. Own, "Learner readiness for online learning: Scale development and student perceptions,” Comput. Educ., vol. 55, no. 3, pp. 1080-1090, 2010.

[19] Y. Hao, "Exploring undergraduates' perspectives and flipped learning readiness in their flipped classrooms," Comput. Human Behav., vol. 59, pp. 82-92, 2016.

[20] A. H. H. Rohayani, Kurniabudi, and Sharipuddin, "A Literature Review: Readiness Factors to Measuring e-Learning Readiness in Higher Education,” Procedia Comput. Sci., vol. 59, no. Iccsci, pp. 230-234, 2015.

[21] T. Wanner and E. Palmer, "Personalising learning: Exploring student and teacher perceptions about flexible learning and assessment in a flipped university course," Comput. Educ., vol. 88, pp. 354-369, 2015.

[22] W. Al-Rahmi, A. Aldraiweesh, N. Yahaya, Y. Bin Kamin, and A. M. Zeki, "Massive Open Online Courses (MOOCs): Data on higher education,” Data Br., vol. 22, pp. 118-125, 2019.

[23] J. Wong, M. Baars, D. Davis, T. Van Der Zee, G. J. Houben, and F. Paas, "Supporting Self-Regulated Learning in Online Learning Environments and MOOCs: A Systematic Review," Int. J. Hum. Comput. Interact., vol. 35, no. 4-5, pp. 356-373, 2019.

[24] R. Yilmaz, "Exploring the role of e-learning readiness on student satisfaction and motivation in flipped classroom," Comput. Human Behav., vol. 70, pp. 251-260, 2017.

[25] M. L. Hung, “Teacher readiness for online learning: Scale development and teacher perceptions," Comput. Educ., vol. 94, pp. 120-133, 2016.

[26] T. Yu and J. C. Richardson, "Examining reliability and validity of a Korean version of the Community of Inquiry instrument using exploratory and confirmatory factor analysis,” Internet High. Educ., vol. 25, pp. 45-52, 2015.

[27] G. H. E. Gay, “An assessment of online instructor e-learning readiness before, during, and after course delivery," $J$. 
Comput. High. Educ., vol. 28, no. 2, pp. 199-220, 2016.

[28] S. W. Van Rooij and K. Zirkle, "Balancing pedagogy, student readiness and accessibility: A case study in collaborative online course development," Internet High. Educ., vol. 28, pp. 1-7, 2016.

[29] Z. Jusoh and L. Abdullah, "Online survey of reading strategies (OSORS): students' online reading in academic context", Malaysian Journal of Distance Education, vol 17, no. 2, pp. 67-81, 2015.

[30] [30] T. Nguyen, "The Effectiveness of Online Learning: Beyond No Significant Difference and Future Horizons,” vol. 11, no. 2, pp. 309-319, 2015.

[31] M. Kurucay and F. A. Inan, "Examining the effects of learner-learner interactions on satisfaction and learning in an online undergraduate course," Comput. Educ., vol. 115, pp. 20-37, 2017.

[32] H. Kauffman, "A review of predictive factors of student success in and satisfaction with online learning," Res. Learn. Technol., vol. 23, no. 1063519, pp. 1-13, 2015.

[33] Ö. Kırmız1, "The influence of learner readiness on student satisfaction and academic achievement in an online program at higher education,” Turkish Online J. Educ. Technol., vol. 14, no. 1, pp. 133-142, 2015.

[34] J. Gillett-Swan, "The Challenges of Online Learning: Supporting and Engaging the Isolated Learner,” J. Learn. Des., vol. 10, no. 1, p. 20, 2017.

[35] B. Toven-Lindsey, R. A. Rhoads, and J. B. Lozano, "Virtually unlimited classrooms: Pedagogical practices in massive open online courses," Internet High. Educ., vol. 24, pp. 1-12, 2015.

[36] R. A. Rashid \& M. F. A. Rahman, "Social networking sites for online mentoring and creativity enhancement", Int. J. Technology Enhanced Learning, vol 6, no. 1, 2014.

[37] R. A. Rashid, S. B. Mohamed, M. F. A. Rahman and S. N. W. Shamsuddin. "Developing speaking skills using virtual speaking buddy", International Journal of Emerging Technologies in Learning, vol 12, no. 5, 2017.

[38] I. Practice and I. Resources, "Learning and Teaching Services,” pp. 1-3, 2016.

[39] J. Morahan-Martin, “The Gender Gap in Internet Use: Why Men Use the Internet More Than Women - A Literature Review," Cyberpsychology Behav., vol. 1, no. 1, 2009.

[40] C. Greenhow and C. Lewin, "Social media and education: reconceptualizing the boundaries of formal and informal learning," Learn. Media Technol., vol. 41, no. 1, pp. 6-30, 2015.

[41] T. Adamus, M. Kerres, B. Getto, and N. Engelhardt,
"Gender and E-Tutoring - A Concept for Gender Sensitive E-Tutor Training Programs," in 5th European Symposium on Gender \& ICT Digital Cultures: Participation Empowerment - Diversity, 2009.

[42] P. Bruestle et al., "Doing E-Learning/Doing Gender? Examining the Relationship between Students' Gender Concepts and E-learning Technology," in 5th European Symposium on Gender \& ICT Digital Cultures: Participation - Empowerment - Diversity, 2009.

[43] M. Cuadrado-García, M. E. Ruiz-Molina, and J. D. Montoro-Pons, "Are there gender differences in e-learning use and assessment? Evidence from an interuniversity online project in Europe,” Procedia - Soc. Behav. Sci., vol. 2, no. 2, pp. 367-371, 2010.

[44] A. Nardozi, "An Exploration of Teacher Candidate Willingness and Readiness To Incorporate Aboriginal Content Into Their Teaching Practice,” University of Toronto, 2016.

[45] T. Yu and J. C. Richardson, “An exploratory factor analysis and reliability analysis of the student online learning readiness (SOLR) instrument," Online Learn., vol. 19, no. 5, pp. 120-141, 2015.

[46] MALAYSIA EDUCATIONAL STATISTICS, "Quick facts 2018", Malaysia Educational Statistics, Putrajaya, July-2018.

[47] R. V. Krejcie and D. W. Morgan, "Determining sample size for research activities", Educational and Psychological Measurement, vol. 30, pp. 607-610, 1970.

[48] R. L. Oxford, Language learning strategies what every teacher should know. Boston: Heinle \& Heinle, 1990.

[49] L. Fedynich, K. S. Bradley, and J. Bradley, "Graduate students' perceptions of online learning,” Res. High. Educ. J., vol. 27, no. 27, pp. 1-13, 2015.

[50] J. R. Tayag, "Pedagogical support for blended learning classrooms: interfacing teacher and student perspective," Universal Journal of Educational Research, vol. 8, no. 6, pp. 2536- 2541. 2020.

[51] A. Tongpoon- Patanasorn and C. White, "Teachers' and students' perceptions on blended learning in tertiary English language courses: a match?," Universal Journal of Educational Research, vol. 8, no. 6, pp. 2455-2463. 2020.

[52] MINISTRY OF HIGHER EDUCATION, "Establishment of research university in Malaysia", Concept paper prepared by Ad Hoc Committee on Establishent of Research University in Malaysia, pp.27 (unpublished).

[53] S. M. Thang, K. W. Lee, P. Murugaiah, N. Mohd Jaafar, C. K. Tan, and N. I. Ahmad Bukhari, "ICT Tools Patterns of Use among Malaysian ESL Undergraduates,” GEMA Online J. Lang. Stud., vol. 16, no. 1, pp. 49-65, 2016. 